\title{
Bir Haklılaştırma Zemini Olarak Doğal Hukuk
}

\author{
Ridvan KÜÇÜKALİ \\ Yrd.Doç.Dr., Atatürk Üniversitesi Felsefe Bölümü Bilim Tarihi Ana Bilim Dalı Başkanı \\ E-mail: ridvankucukali@ atauni.edu.tr
}

\author{
Hasibe AKBAŞ \\ Yüksek Lisans Öğrencisi, Atatürk Üniversitesi Felsefe Bölümü \\ E-mail: hasibe_akbas-2011@hotmail.com
}

$\ddot{O}_{z e t}$

Bu çalı̧̧mada amacımız, doğal hukukun tanımını, literatürdeki yeri ve önemini belirleyerek, hak ve hukuk kavramlarl zemininde etki ve önemini vurgulamaktır. Başka bir deyişle; doğal hukukun yürürlükteki hukuk normlarının dışında, içeriği doğal olarak var olan, her zaman ve her yerde geçerli olan; bununla birlikte akll ve mantıkla normlarına ulaşılabilen, yazll olmayan bir hukuk kuralı olarak, diğer hukuk kuralları ile arasında önemli nüanslar bulunmaktadır. Bu hususları dikkate aldığımızda, doğal hukukun sevgi ve saygıya dayalı hümanist yaklaşımı ve diğer normlara göre daha ideal ve evrensel bir tutum sergilemesi doğal hukuku, diğer hukuk kurallarından üstün kilmıştır. Şöyle ki; doğal hukuk, herhangi bir gelenek, görenek ve normun etkisi altında kalmadan, insanların doğal yollardan ulaştıkları hukuk anlayışı diyebiliriz. Yani bu kurallardan insanlar doğrudan etkilenmekle birlikte, uygulanması için herhangi bir iç ve dlş kuvvete ihtiyacı yoktur. Kendiliğinden gerçekleşen doğal hukuk, insanlığın ilk çağından bu zamana gelişsen hukuk kurallarının da temelini oluşturmuştur. Sosyal yaşamın en büyük parçası olan insanlar arası karşıllklı iletişim ve etkileşimin yüzyıllar boyu ilerleyip, gelişsmesinde doğal hukukun önemli bir rolü vardır. Çünkü insanlığın ilkçağlarında insanlar arasındaki ilişkileri düzenleyen sözlü veya yazll hukuk kuralları yoktu. O zamanlar doğal yaşamın getirdiği doğal kurallar vardl. İnsanlarda buna doğal olarak uyum sağllyordu. İnsanlığın ilerleyebilmesi için bu uyum şarttı ve bu ancak o çağlarda doğal hukukla sağlanacaktı. Bu nedenle doğal hukuk aslında geçmiş ve gelecek tüm çağlar için referans olacak bir hukuk kuralıdır. Çağlar arasında ne kadar farklllik olursa olsun insanlar arasinda her zaman temel bir takım haklar sorun olacaktır. Şöyle ki; yaşama, özgürlük, sağllk, eğitim, barınma gibi insan hayatını derinden etkileyecek olan kavramlar, çağlar arasında farklılıklar olsa bile bir problem olarak aynı kalacaktır. Bu problemde ancak insanların vicdanı ile birlikte özgürlüklerini başkalarının hayatlarına müdahale etmeyecek şekilde yaşamasıyla aşılacaktır. Bu sorunun çözüme kavuşmasinda da doğal hukuk en temel nosyondur.

Sonuç olarak, doğal hukukun geçmişteki yeri ve gelecekteki önemini belirleyerek, insanoğluna alternatif çözümler sunmasıyla problemlerin çözümünde evrensel ve çok yönlü bir düşünme sağladı̆̆ vurgulanmıştır. Bununla birlikte, doğal hukukun tüm hukuk kurallarının temelini oluşturduğu, ortaya çıkan hukuk kurallarının bu çerçevede şekillendiği ifade edilmiştir.

Anahtar Kelimeler: Doğal, doğal hukuk, evrensel, hak, hukuk, evrensel.

\section{The Natural Law As A Justification Ground}

\footnotetext{
Abstract

Our aim in this study is to emphasize the definition of natural law, the influence and importance of natural law in the rights and legal ground by determining the role and importance of literature. In other words, there are important differences among other law rules as unwritten law rules in the content of the natural law which exists naturally, is available always and in everywhere reachs norms with the reason and logic apart from the law norms in
} 
force. When we pay attention to these issues, the humanistic approach of natural law based on love and respect and compared to other norms, the manner of which behaves in a more ideal and internatioan way shows that it is superior to other law. Namely the naturel law witout being under the influence of any traditions and norms we can say that it is a law in which people reach it directly. So there is no need to any internal and external forces although it effects people directly. Spontaneously occuring natural law from the first era of humanity to today, it has formed the basis of developing natural law. There is an important role of natural law in the mutual communication and interaction among people who are the largest part of social life that it has progressed and developed for ages because there was no written or unwritten law rules , which organises relationship among people, in the first era of humanity. At that time there were natural rules that was coming from natural life. People were adapting these rules naturally. This adaptation was essential to improvement of mankind and for this improvement there was only one way " natural law" Therefore natural law rules are reference rules for old and future ages. No matter how much differences between ages, some inherent rights will be problem among the people. In other words concepts, which have an effetct on people's lives like living, harboring, health, liberty and education, will stay a problem despite the differences of ages. This problem will be solved if people live fairly and without interfering in other people's lives. To solve this problem natural law is the most essential notion.

As a result it is emphasized that to solve the problems multiple and universal thinking is provided to mankind with determining the place of natural law in the past and importance for future. In addition it is stated that natural law is the base for all law rules and these rules are shaped in this frame.

Keywords: Law, natural, natural law, right, universal.

Bu araștırmada elde edilen bulguların bir bölümü veya tamamı 12-14 Kasım 2015 tarihleri arasından düzenlenen "Felsefe, Eğitim ve Bilim Tarihi” adlı sempozyumda sözlü bildiri olarak sunulmuștur.

\section{Giriș}

Nasıl etik alanda, insanların eylem ve yapıp-etmenlerini, ilişkilerini yöneten ilkeler, değerler varsa, bir topluluk içinde yaşayan insanların eylemlerini, birbirleriyle olan ilişkilerini yönetip düzenleyen ilkeler ve bu ilkelere dayanılarak konulan kural ve yasalar vardır ki, bunların hepsine birlikte hukuk sistemi adını veriyoruz(Mengüşoğlu, 2008:s.276). Bu anlamda, ilk kez sofistler, insanın insan olarak sahip olduğu, onun 'Doğa'sından gelen hakları içeren doğal hukuk ve insanın kendi yarattığ 1 , kendi koyduğu pozitif hukuk düzenleri arasında ayırım yapmışlardır (Özlem, 2001:s.427). Böylece hukuk kuralları, genellikle bu iki kavram üzerinden şekillenmiştir.

$\mathrm{Ne}$ zaman siyasetten söz etsek, aynı zamanda doğrudan, yanlıştan, adalet, adaletsizlikten, haktan ve haksızlıktan da bahsederiz. Bazı yasa ve kararları iyi diye överken, bazılarını da kötü diye lanetleriz. Sık sık insan iradesi ile değiştirilemeyecek nitelikte bir takım doğru ve yanlış standartlarının siyasete, hukukta ve insan yaşamın da yer aldığını öne süreriz. Sonuçta, tam olarak farkına varmasak da doğal hukuk fikrini bir şekilde kabul etmiş oluruz (Arnhart, 2008:s.134). İnsanın kendisine vazedilen yasaların haklılığından kuşku duyup, pozitif hukukun kendisine başvurularak değerlendirilebileceği daha yüksek bir yasayı araştırmaya yönelişinde kaynağını bulan doğal hukuk düşüncesi, çağdaş dünyanın taşıdığ 1 değerlerin önemli bir kısmını kendisinden miras aldığ1 bir gelenektir. O, iki bin yılı aşkın bir süredir varlığını sürdüren, haklı ile haksızın ayırt edici ölçütünü ortaya koyma çabalarının sergilendiği; insanın en iyi toplumsal yaşama ulaşmasında neyi ölçüt alması gerektiğini gösterme çabalarının ortaya konulduğu bir gelenektir. Bu geleneği önemli kılan şey, toplumsal yaşamın en önemli öğelerinden birini, hukuku konu edinmesinden ve toplumda yaşayan insanın istemekten hiçbir zaman vazgeçmediği adaleti sorgulamasından kaynaklanır.

\section{Doğal Hukuk Nedir?}

Doğal hukuk; aklın ışığıyla öğrenilebilen, rasyonel doğaya neyin uyup neyin uymadığını gösteren ve bu nedenle de emredici veya yasaklayıcı olan, tanrısal iradenin bir buyruğu şeklinde tanımlanabileceği gibi, apriori olarak metafizikten, insanın doğasından ya da adaletin özünden çıkarılan norm şeklinde de tanımlanabilir (Toku, 2004:s.236). Bu farklı1ık, bir yandan doğal hukuk düşüncesini ortaya koyan düşünürlerin yaşadıkları 
dönemlerin karakteristik özelliklerinden etkilenmesine, diğer yandan düşünürün dünya görüşü ve felsefesi çerçevesinde yeni bir șekil kazanmasına bağlanabilir. Yine bu nedenlere paralel olarak, Doğal hukuk kuramcıları, hukuka rasyonel bir temel sağlayacak olan ilkenin, ancak bütün insanlarda ortak olan bir doğadan çıkarsana bileceği düşüncesiyle yöneldikleri doğaya farklı anlamlar yüklemişlerdir. Doğa, kimi zaman rasyonel bir düzeni, kimi zaman tanrının yarattığı kutsal bir niteliği, kimi zamanda saflığa delalet etmiştir. Bütün bu farkl1lıklara rağmen doğa, her zaman, insan ürünü olmayana, tarihsel olmayana, her türlü insansal yaratımın ard-alanı olacak olana işaret eden bir yapı olmuştur.

Doğal hukuk düşüncesinin amacı, bireyin kendisine zorla buyrulan bir yasayı değil, aynı zamanda kendisini ifade ettiği için ona karşı moral bir yükümlülüğü olan yasaya uymasını sağlayacaktır. Bununla birlikte, bireyin bu yasaya uygun bir şekilde davranarak kendisine en uygun yaşam biçimine ulaşmasının yolunu gösterecek bir toplum ve hukuk anlayışı ortaya koymak olan bir düşüncedir. $\mathrm{Bu}$ düşünce kimi zaman, Roma İmparatorluğunun evrensel hâkimiyetini savunmak için temel oluştururken, kimi zamanda klişeleşmiş eski hiyerarşilerin yıkılıp, daha alt sınıfların politik güce katılma isteklerini ifade eden bir düşünce olmuştur. Hatta kimi zaman bizzat devrimi meşrulaştırmışlar ya da devrimlerin kendilerini temellendirecekleri zemini sunmuşlardır. Ama her durumda onlar, kendi çağlarının öz-bilinci olan fakat geleceğe de kapı aralayan kuramlar olmuşlardır.

Doğal hukukun ne olduğunun tam olarak ortaya konabilmesi için onunla pozitif hukuk arasındaki benzerlik ve farklılıkların ortaya konması gerekir. Yani doğal hukuk bir toplumun formel, legal yasaları anlamındaki pozitif hukuktan ayırt edilmelidir. İnsanlar tarafindan uzlaşım yoluyla yaratılan pozitif hukuk, doğal hukukun aksine objektif bir şekilde ortaya çıkmamıştır. Pozitif hukuk aklın dayattığı, doğal hukuksa keşfettiği şeydir. Muayyen bir toplumun formel, legal yasaları anlamında ki pozitif hukuk, devlet tarafindan formüle edilen ve yaptırım gücü devlete dayanan hukuktur, ancak doğal hukuk, vicdani bir uygulamadır. Doğal hukuk, insan eseri olmayan ve gerçekliğin temelini oluşturan doğa yasasıdır; ancak pozitif hukuk, insan eseridir ve onun gerçekliğinin temelini oluşturan onları yaratan beşeri faktördür. Değişmez kurallardan ibaret olan ve insanlar tarafindan keşfedilen doğal hukuk, doğal olarak bilinebilen moral hukuktur. Aynı zamanda doğal hukuk, deskriptife değil normatife olması hasebiyle ontolojik değil, deontolojik bir düzendir. Pozitif hukuk, yürürlükte olan ve tarihi süreç içerisinde insanlar tarafından tasarlandığı için de değiştirilebilme imkânına haizdir. Bundan dolayı pozitif hukuk, onu uygulayan devletlerin karakteristik özelliklerine uygun bir biçimde değişebildiği gibi dönemlere göre farklılık da arz etmektedir. Fakat doğal hukuk, niteliği itibariyle her zaman ve zeminde tüm insanlar için geçerli olan değişmez bir mahiyettedir (Aral, 1991:s.197198). Temel itibariyle zorlamaya dayalı bir hukuki yapılanma olan pozitif hukuk, bizatihi uygulamasını sağlayacak bir güçten kaynaklanmadığı için uygulanabilirliğini zorlama ya da yükümlü kılma yoluyla sağlamaya çalışır. Dönemler arasındaki farklılıklara göre değişiklik gösteren pozitif kanunların dışında, her zaman ve zeminde tüm insanlar için aynı olan ve insanoğlunun kendi iyiliğine yönelik, kendisine rasyonel rehberlik yapabilecek olan hukuk doğal hukuktur. Doğal hukukun pozitif hukukla ilişkisin temelde, pozitif hukukun temelinde yer almak, ona esin kaynağı olmak ve bu hukuku kontrol etmek anlamında üç işlevi vardır. Doğal hukukun pozitif hukukla ilgili bu işlevleri, genel olarak, doğal hukukun adalet, eşitlik ve özgürlük gibi ilkeleri içermesiyle ve bu ilkeler 1şığında pozitif hukuku denetlemesiyle açıklanabilir. Yine bu bağlamda, doğal hak hukukunun savunucuları, bağlayıcı olduğu savunulan hukukun geçerliliğini, insana verilmiş doğanın değer ve anlamlılığından türetmiştir. Bu bağlamda, pozitif hukukun yandaşları, böyle bir doğanın olmadığını ve hukukun geçerliliğginin yalnızca yasalara bağlanmış olan hukukla, yani insanların karşılıklı ilişkilerini düzenlemek için ortaklaşa kararlaştırdıkları ve yazılı olarak kesinleştirip kâğıda döktükleri genel bağlayıcı yasalarla ilişkili olduğunu iddia etmektedirler (Pieper, 2012: s.65.).

Doğal hukuk, hukukun kaynağını adalet olarak sunan hukuk akımıdır. Pozitif hukuk ise hukukun kaynağını devletin egemenlik yetkisi olarak belirlemiştir. Doğal hukuka göre, bir norm adalete uygunsa hukuka da uygundur. Pozitif hukuka göre ise, devletin koyduğu 
tüm kurallar hukuka uygundur. Normun içeriğinin önemi yoktur. Adalet gibi soyut bir kavram kıstas olarak kabul edilemez. Tabiî hukuk teorisi adalet kavramını kendine göre tanımlar ve bu kavramı kendi teorisinin merkezine yerleştirir. Hukukî pozitivizm ise, tabiî hukukun adalet tanımlarını eleştirir ve bu kavramın tanımlanamaz bir kavram olduğunu ve bu nedenle de hukuk biliminin dışına itilmesi gerektiğini ileri sürer. Tabiî hukuk anlayışında, bizatihi hukuk, adalet ile tanımlanır. Hukukun geçerliliğini kuran şey adalettir. Bu açıdan tabiî hukuk teorisini kısaca 'bir kanun, kanun olmak için adil olmak zorundadır' diyen bir anlayış olarak tanımlayabiliriz. Kısacası, bu anlayışta 'geçerli olan hukuk, âdil olan hukuktur'. Pozitif hukuk ancak adaletin gereklerine uyduğu ölçüde geçerlidir. Belirli bir insan davranışı konusunda yöneltilen bir emir âdil değilse geçersizdir, yani hukuk normu değildir. Tabiî hukuk teorisi, pozitif hukukun geçerliliğinin temelini sorgular. Pozitif hukukun neden geçerli olduğu sorusunu sorar ve bu soruya kategorik yani şartsız bir cevap verir. Pozitif hukukun geçerliliğinin temeli adalettir. Pozitif hukukun içeriği tabiî hukuka, yani adalete uygun ise geçerli; değilse geçersizdir. O halde tabiî hukukçulara göre, tabiî hukuk âdil olması itibarıyla tek gerçek hukuktur. Pozitif hukuk ancak tabiî hukuka uygun olduğu ölçüde hukuktur. Özetle tabiî hukuk anlayışında bir hukuk kuralının geçerliliğinin ölçüsü onun adilliğidir(Gözler,2008:s.77-90).

Doğal Hukuk, elbette ki her zaman insanoğlunun ilgisini çeken cazip bir alan olmuştur. Çünkü doğal hukukun getirdiği doğal hak ve özgürlükler; sınırları çizilmiş, determinist bir alana göre çok fonksiyonlu, köklü ve canlı bir kılavuzdur. Bu bağlamda, yine geçmişten geleceğe bir referans olarak da irdelenen doğal hukuk, insan- tabiat ilişkisindeki muazzam dengeyi sağlayan, zayıf ile güçlü arasındaki ilişkiyi rayına oturtan önemli bir nosyondur. Doğal hukukun yapısında doğal bir hiyerarşi söz konusu olduğu için doğal olarak kaosa yer yoktur. Bu nedenle de herhangi bir yaptırım gerektirecek normlara da gerek yoktur. Doğal hukuk bünyesindeki insanlar, doğal hak ve özgürlüklerin farkında olmakla birlikte, bu doğal yaşama uyum sağlamanın da bilincindedir. Şöyle ki; doğal hukukun hüküm sürdüğü zamanlar insanlara adaletli ve eşit şekilde davranılıyordu. Herkes aynı haklara sahipti. Doğal hukukun etkin olduğu dönemlerde insanlar arası iletişim ve etkileşimlerde, herkesin birbirine sayg1 ve sevgi duyduğu hümanist bir yaklaşım hâkimdir. Böylece herkes hak ve özgürlüklerinin bilincinde olup, bu çerçevede hareket etmektedir. Bu bağlamda, insanlar ihtiyaçları doğrultusunda alacağını alır, ihtiyacı fazlasina dokunmazdi.

Bunun akabinde pozitivist yaklaşımın getirdiği pozitivist dönem, pozitivist hukuku da beraberinde getirdi. Yani, insanın daha rahat ve konforlu bir hayat istemesi sonucu, ihtiyacı fazlasına yönelmesi ve onu üretmesi ile meydana gelen rekabet ortamı insanoğlunu vahşileştirmeye başlamıştır. Çünkü kendi dışında hiçbir otoriteyi kabul etmek istemeyen insanoğlu, başkasına itaat etmemek için her zaman en etkin güç olmaya çalışmıştır. Bu nedenle de çağının güç kaynağı olan hangi disiplinse yani din, bilim, ekonomi vs. gibi kavramlardan hangisi aktifse, o nosyonu elinde bulundurarak yaşadığı dönem ve çağda prestij sahibi olmaya çalışmıştır. Etkin güç olmanın cazibesine kapılan insanoğlu artık isteklerine 'dur' diyemeyen bir pozisyon almıştır. Böylece insanoğlunun ilgisi, merakı, kıskançlığı, her şeyin en iyisini elde etme arzusu tehlikeli bir hal almaya başlamıştır. İhtiyaçları dışında konfor ve rahatı için ve bununla birlikte diğer insanlardan daha üst seviyelerde olma isteği ile her türlü gücü elinde bulundurarak kendi soydaşlarını bile bir kukla gibi oynatmak isteyen insanı durdurmak; ancak caydırıcı, çeldirici yöntemlerle olacaktır. İşte bu nokta da devreye pozitif hukuk girmektedir. Aslında son zamanlarda doğal hukuktan çok pozitif hukuktan bahsedilmesinin nedeni de; insanın bu kör hevesinden kaynaklanmaktadır. Bir başka deyişle, doğal hukukun dejenere olması sonucu ortaya çıkan pozitif hukukun, normlarına uyulmadığı takdirde yaptırımları vardır. Çünkü pozitif hukuk tasavvurunda insanlar arası iletişim, etkileşim ve hiyerarşi ancak insanlar arası sözleşme ve normlarla sağlanmaktadır. Bu nedenle kurallar ve yaptırımlar genel anlamda insanların isteklerini sınırlayıcı bağlamdadır. Şöyle ki; gücü elinde bulunduran, yine bu pozitif hukukun ortaya çıkmasında etkin rol oynayan kişiler olmakla birlikte, genelde insanlar arası güç dengesini sağlamaya çalışsa bile, elbette bunu tam anlamıyla başarması mümkün değildir. Çünkü elde ettiği söz söyleme hakkı ile herkese 
eşit ve adaletli davranırsa, herkesten bir farkı kalmayacağı için herhangi bir ayrıma gitmesi de söz konusu olmayacaktır. Bu nedenle prestij ve gücünün de bir önemi kalmayacaktır. $\mathrm{Bu}$ da insanoğlunun hiç hoşuna gitmeyecektir. Her zaman övülmeyi seven, başarısı ve gücüyle adından söz ettirmeyi isteyen insanoğlu, bunun içinde gerekli olan her şeyi yapacaktır. Bu nedenle doğal hukuk-güç arasındaki ilişki önemli olmakla birlikte -birkaç paragrafla anlatılacak kadar da kısa olmadığı için- çalışmamızın sınırlılığı açısından bu kadar değinebildik.

Savunan düşünürler, Doğal hukuku pozitif kanunların üzerinde yer alan kusursuz bir kanun olduğunu ifade etmişlerdir. Doğal hukuk doğanın kanunlarının insanın doğasına kazındığını ve yaşayan her şeyin hukukuna temel oluşturduğunu savunur. Bu düşünce tarzı Antik Yunan filozoflarına kadar gitmekteyse de Stoacı filozoflar ile sistemleşmiş, Cicero ve Aquinas tarafından da Orta Çağ'a taşınmıştır. Maturidi, Hobbes, John Adams, John Locke, Thomas Jefferson, Madison, Leibniz, Vattel, Rousseau, Kant, Montesquieu gibi düşünürlerce çağdaş zamanlara dek sürdürülmüştür. İlk olarak Eflatun'un ve Aristoteles'in yasalara ait felsefeleri sonucunda doğal hukuka dair düşünceler oluşmuştur. Araştırmacılar bazen Eflatun'u doğal hukukun temsilcisi sayar. Gorgias ve Timaeus diyaloglarındaki fikirleri doğal hukuk içerisinde değerlendirilir(Wild,1953:s.1). Onun öğrencisi olan ve birçok bilimin öncüsü sayılan Aristoteles de bu kurama örneklendirilen fikirler öne sürmüştür(Wacks,2006:1-4).

Tarihi tezahürleri itibariyle bakıldığında, doğal hukuk öğretisinin birkaç formundan bahsetmek mümkündür. Doğal hukuk düşüncesi, ilk önce Antik Yunan'da, bütün unsurları, ebedi ve ezeli, değişmez bir hukuk tarafından yönetilen evren düşüncesiyle ortaya çıkmıştır. Mesela, Strauss'a göre, 'doğa' kavramı insanlık tarihi kadar eski değildir. Ona göre, Eski Ahit'te bir 'doğa' kavramı ve dolayısıyla bir doğa yasası kavramı yoktur. 'Doğa', ilk kez Yunanlılar tarafından keşfedilmiş ve ardından felsefenin ilk teması olmuştur (Strauss, 1953:s.1-9). Doğa filozoflarında ortaya çıkan 'doğa' kavramı, değişmez veri olan bir şeye işaret ediyordu fakat bu kavram bir kılavuz ilke olarak değil, açıklayıcı bir ilke olarak sunuluyordu. Hukukun dayanağı olacak olan bir 'doğa' kavramının ortaya çıkabilmesi için, kozmosun parçalanması gerekmektedir. Çünkü hukukun otonom bir araştırması ve hukuk-doğa ilişkisinin bir doğal hukuk kuramı oluşturacak bir biçimde kurula bilmesi için, insansal olan, yapma olan bir şeyin kendisiyle ilişkiye sokulabileceği bir 'doğa' gereklidir. Bundan dolayı bu alanların birbirinden ayrılması gereklidir, çünkü ayrımlaşmamış bir bütün içindeki parçaların ilişkisinden söz etmek imkânsızdır. Öğretinin bu ilk klasik formülasyonu Stoacılara aittir. Onlara göre, fiziksel doğanın yanında birde insansal doğa vardır. İnsan doğası evrensel ve mutlak güdülerin toplamıdır ve bu güdüler toplumdan topluma değişmez. İnsanlar, herhangi bir dişsal zorunluluktan ötürü değil, özgür iradeye sahip olduklarından, hukuka itaat ederler. Eğer insanlar kendi doğalarında var olana uygun bir şekilde hareket ederlerse o takdirde doğal hukuku izlemiş olurlar. Başka bir deyişle ilk kez sofistler insanın varoluş itibariyle getirdiği ve kendi doğasının bir ürünü olarak ortaya çıkan doğal hukuku problem edinmişlerdir.

Doğal hukuk kavramı geçmişten günümüze gelene kadar birçok kez farklı şekilerde ifde edilmiş ve değişikliklere uğramıştır. Tarihsel gelişimde en eski görüş Platon ve Aristoteles ile başlayıp, Cicero tarafindan formüle edildiğini görmekteyiz. Aslında bu dönemde doğal hukuk adı altında genel bir kategoriden hareket edilmemektedir. Stoacılar, sofistler de kendi dünya görüşlerinden hareketle doğal hukuka atıfta bulunmuşlardır. 'İnsan nasıl yaşamalı' sorusuna bu dönemde 'Doğaya/insan doğasına uygun biçimde' cevab1 verilmiştir(Türker,2005:s.135-165).

Sofistler tarihte ilk kez insanlar arasında eşitlik esasını savunup, köleliğe karşı çıkmış ve tek Doğal Hukukla yönetilen insanlara tek Evrensel Devlet altında birleşmelerini salık vererek tarihte gene ilk kez 'Birleşmiş Devletler' fikrini ortaya atmışlardır. Bunları yaparken de, meşrulaştırma zemini olarak, evrene ve insana hâkim olan, doğuştan, kendiliğinden gelen bir doğal hukuk fikrine başvurmuşlardır. Daha önce de ifade ettiğimiz gibi doğal hukuk fikri, kimi zamanda klişeleşmiş eski hiyerarşileri yıkan, kimi zamanda bizzat devrimi meşrulaştırmışlar ya da devrimlerin kendilerini temellendirecekleri zemini sunmuşlardır. Sofistler de düşünce tarihinde ortaya koydukları devrim niteliğindeki 
fikirleri temellendirmek için doğal hukuk fikrine başvurmuşlardır. "Yine sofistlerin yaptığı temel ayrımlardan biri, 'doğa-yasa' ve 'doğal olan-yasal olan' ayrımıdır. Sofistler genel olarak doğal olanı insanın özüne uygun, dolayısıyla doğru ve iyi olarak kabul ederler. Yasal olan ise onlara göre, insanın özüne aykırı, yalnızca toplumun ve uylaşımın (convention) sonuçları olan şeydir ve dolayısı ile yapay ve kötüdür" (Arslan, 2005:s.191).

Orta Çağ'da doğal hukuk düşüncesi dini bir motif almaya başlamıştır. Hıristiyan teologlar, tanrısal dinsel hukukla doğal hukuku aynileştirirken, Stoacıların doğal hukuk teorisini kendilerine rehber edinmişlerdir. Bu dönemin doğal hukuk anlayışı genellikle Thomas Aqinas'ın yaklaşımıyla paralellik gösterir. Burada doğal hukuk, Tanrı'nın yarattığı evrendeki her şeyi yönettiği yasa olan ebedi hukuka dayandırılır. Başka bir deyişle doğal hukuk, rasyonel yaratıkların bu ebedi hukuka katılımından başka bir şey değildir (Arnhart, 2008:s.137). Thomas der ki, her şey, akılsız hayvanlar ve akıllı insan ilahi akla, ebedi hukuka uyar. Yalnız insan, akıllı bir varlık olarak, ilahi inayete ve akla özel bir yolla katılarak; hakeza o kendinin ve başkasının hayatına müdahale eder, hâlbuki Tanrı'nın bütün düğer yaratıkları, akılsız hayvanlar ve cansız nesneler, ilahi aklı, belli davranışlar ve amaçlar için gerekli olanı ilahi akıldan alarak yansıtırlar. Bundan dolayı, doğal hukuk, insanın etkin ve kişiler (insanlar) arası akliliğidir, onun 'ebedi hukuka katılımıdır (Ebenstein, 2005:s.125). "Demek ki, Aristoteles'te olduğu gibi, Aquinalı Thomas'ta da insanın kendi doğal iyisine ancak toplum içinde ulaşabilen sosyal bir hayvan olması nedeniyle politika ahlaktan ayrılmaz veya onu tamamlamak durumundadır. Bununla birlikte, Thomas açısından devlet, sadece insanın doğal amacını gerçekleştirebileceği çevre olmakla kalmaz; o, aynı zamanda insanı doğaüstü amacına hazırlayacak bir araçtır da." (Cevizci, 2009: s.354).

Doğal hukuk bir özgürlük bayrağı olması nedeniyle, Hıristiyanlarca büyük ölçüde benimsenmişti. Ancak kilise babaları din eksenli kendi dünya görüşlerini benimsetmek için doğal hukuku derin bir biçimde değiştirmişlerdir. Çünkü kilise dünya hegemonyası için uğraşıyordu ve bu hâkimiyeti sağlamak içinde köleliğe karş1 özgürlüğü savunur görünmüş̧; despot yöneticiler karşısında, Tanrısal alana bağımlılığın gerçek özgürlük olduğunu öne sürmüştür. Bütün bunları temellendirirken de Tanrısal evrenin sonsuz yasası anlamına gelen Lexaeterna ilkesine dayandırılan doğal hukuk fikrine başvurmuşlardır. İlahi düzenin yasaları olan ebedi yasaları insan aklı algılayamaz, ancak yalnızca bu yasaların dinsel olan kısmı yani Lexdivina (ilahi yasalar) din adamlarınca algılana bilir. Düşünen insan aklının Lexaeterna içinde algılayabileceği bölümü oluşturan doğal yasalar, insanlara toplumsal yaşam içinde rehber olmalıdır ancak insanlar, Lexaeterna'yı ilk günahtan dolayı tam olarak algılayamazlar. İşte tam da bu noktada kendi dünya görüşlerini dayatmak için muazzam bir güç elde ediyorlardı. Çünkü bu yasaları tam olarak algılayabilecek olanlar kilise babalarıdır. Bireylerin ve devletlerin bu yasalara uymaları zorunluydu.

İlkçağın ardından doğal hukuk düşüncesi fazla gündeme gelmemiş ve Rönesans'ın başlamasına kadar neredeyse unutulmuştur. Rönesans döneminde; Reformaysan hareketleri ve hümanizm akımına bağlı olarak meydana gelen toplumsal sekülarizasyon sonucunda, doğal hukuk teorisi, insan aklı çerçevesinde yeni bir temele oturtulmuştur. $\mathrm{Bu}$ dönemlerde ekonomik devrimin gerçekleşmesi, kentlerdeki kentsoylu sinıfin zenginleşmesine ve gelişen bu yeni sınıfın siyasal iktidarlar karşısında etkin bir güç haline gelmesine neden olmuştur. Zenginleşmenin sağladığı nimetler mülkiyet kurumunda yeni gelişmelere yol açmıştır. Mülkiyet, merkezi iktidarların sınırsız egemenlik gücü karşısında hak olarak hiçbir şey ifade etmiyordu. Kentsoylular haklarını korumak için felsefi ve sosyolojik gerekçeler aramaya başladılar. Bir takım düşünürler bu amaçla Antik Yunanın doğuştan kazanılan, vazgeçilmez, devredilmez özgürlük, eşitlik ve dünya nimetlerinden yararlanma hakkına dört elle sarıldılar.

$\mathrm{Bu}$ nimetlerden yaralanma haklarını güvence altına almak için XVII. Yüzyılın rasyonalist doğal hukuk anlayışını tasarladılar ve bu anlayış gelişmekte olan toplumsal sınıfın gereksinmelerine çok uygundu. Artık birey doğuştan gelen ve bireyin sırf insan olduğu için sahip olduğu vazgeçilmez, devredilemez haklara sahipti; siyasal otorite keyfi olarak onun özgürlük haklarına ve bunun uzantılarına dokunamazdı. Doğal hukukun dinsel 
temeli sarsılmakta, onun yerini 'akıl' almaktadır. $\mathrm{Bu}$ doğal hukukun sekülarizasyonu demekti. Bu kesinlikle doğal hukukun yeniden yıldızının parlaması anlamına geliyordu. Vurgulamak gerekirse: (i) Hukukun gerçek kaynağı insan aklıdır. (ii) Hukuk laik temellidir. Tanrı iradesine dayalı bir doğal hukuk yoktur. (iii) Hukukun ölçüsü ve kaynağı insandır. (iv) aklın algıladığı matematik ilkeler nasıl değişmez ve saltsa, insan aklının algıladığı doğal hukuk da bütün zamanlar ve uluslar için geçerli, salt ilkelerden oluşan bir bütündür. (v) Rasyonalist doğal hukuk bireycidir ve amacı bireyin mutluluğudur. Bireyin mutluluğu özgür eşit ve mülk sahibi olmasına bağlıdır(Öktem, 1983:s.147). Doğal hukuk daha sonra Rousseau ve Locke'la birlikte sosyal sözleşme ilkesini benimser.

On yedinci yüzyılın önemli düşünürlerinden, Hollandalı hukukçu Hugo Grotius'a göre, doğa ve akıl uyum içerisindedir. İnsan doğası sadece akledebilen değil, aynı zamanda sosyal bir niteliği de içerir. Hukuk insanın sosyal niteliği açısından bir zorunluluktur. Ancak, sadece "akıl tarafından dikte edilen", hayata yönelik kurallar doğaldır (Torun, 2005:s.57-58). Doğal hukuk, insanın evrensel ve değişmez özünden yani doğasından zorunlu olarak türeyen evrensel hukuk ilkelerini içermektedir. Bir diğer deyişle, bir davranışın ya da eylemin yapılması gerektiği yolunda buyruk veren ya da yasak koyan hukuk kuralı "doğal" olacaksa, insan doğasına uygun olmak zorundadır. Tanrı da doğaya ters düşmeyen ve onun ilkeleriyle belirlenen eylemleri kendi iradesi çerçevesinde buyurur ya da yasaklar. Doğal hukuk, Grotius'a göre, tanrısal hukukla özdeş veya Tanrısal hukuka tabi değil, aksine ondan farklıdır ve bağımsızdır. Yani, doğal hukukun kaynağı Tanrısal dinsel hukuk değil, insan aklıdır. "Doğal hukuk değişmezdir. Hatta Tanrı bile rasyonel doğal hukuka riayet ettiğini söylemek mümkündür. Tanrı'nın gücü ne kadar muazzam olursa olsun, bu gücün bile değiştiremeyeceği bir takım şeyler vardır. Bu matematiksel bir ifadeyle şu şekilde dile getirilebilir. Tanrı, kendi hikmetine de aykırı olduğu için, iki kere ikinin dört etmesini nasıl değiştiremezse özü itibarıyla kötü olan bir şeyin iyi olmasını da mümkün kılamaz (Ağaoğulları, Köker, 2004:s.93-95).

Doğal hukukun seküler temele oturtulması süreci, Aydınlanma diye karakterize edilen dönemin entelektüel temellerini oluşturan felsefenin kurucusu, İngiliz düşünür John Locke 'ta zirve noktaya ulaşmıştır. Locke 'un savunmuş olduğu doğal hukuk anlayışının kökleri, Antik Çağ Stoa felsefesine kadar iner. Locke'a göre, doğal hukuk doğanın ışı̆̆ıyla öğrenilebilen, rasyonaliteye neyin uyup neyin uymadığını gösteren ve bu nedenle de emredici veya yasaklayıcı niteliği bulunan, ancak din tarafından bildirilen değil, yalnızca akıl tarafından keşfedilebilen tanrısal iradenin buyruğu olarak tanımlanabilir.

Politik iktidarın, ilahi yönetme hakkı yoluyla değil de, sadece ve sadece bireyden hareketle ve ancak halkın rızası yoluyla temellendirilebileceğini düşünen Locke, doğallıkla toplum sözleşmesinden ve dolayısıyla, politik otoritenin tesisinden önceki doğa durumundan yola çıkar(Cevizci, 2007:s.312). Locke'un 'Yönetim Üzerine İki İncelemesi, doğal hukuk anlayışının pozitif hukuku sorgulama amacının tam olarak ortaya konduğu bir eser olmuştur. İlk kez onunla, insanın devredilmez hakları tesis edilmiş ve yine ilk kez onunla insana ve onun değerine uygun olmayan bir yasaya boyun eğilemeyeceği söylenmiş ve halkın devrim hakkı meşrulaştırılmıştır. Yine ilk kez açık bir ifadeyle toplumda üstün olan gücün halk olduğu ve devletin müdahale edemeyeceği bir alanın var olduğu Locke tarafindan söylenmiştir.

Locke'a göre, doğal hukukun varlığını gösteren birtakım deliller vardır ve bu delillerden en önemlilerinden biri vicdandır. Ona göre, vicdani yargı, doğal hukukun var olduğunu gösterir. Aklın, itaat edilmesini emrettiği doğal hukuk olmasaydı, kanun olmadan herhangi bir yargılama imkânı bulunamayacağına göre, insanların vicdanlarının onların eylemlerini yargılaması ve sonuçta suçlu ya da suçsuz bulması nasıl imkân dâhilin de olurdu? Bundan çıkarılabilecek sonuç, yazılı olmasa da doğal bir hukukun varlı̆̆ıdır(Toku, 2003:s.94). Locke için, doğal hukukun varlığına gösterilebilecek bir diğer delil, evrenin kendi yapısından çıkarılabilir. Evrende mevcut olan her şey, doğalarına uygun var oluş tarzını, tabi oldukları doğal kanunlara bağlı olarak gerçekleştirirler. Evrendeki her şeyin böylesi doğal bağlılıkları varken, insanın olmaması ihtimal dâhilinde değildir. Locke 'un bakış açısıyla, bizatihi toplumsal hayatın kendisi de doğal hukukun varlığına bir delildir. Doğal hukuk olmadan insanlar kendi aralarında hiçbir sosyal 
münasebet ve birlik oluşturamazlar. Çünkü insanların sözleşme yapmalarını ve onu vefalı bir şekilde uygulamalarını sağlayan doğal hukuk olup, doğal hukuk yoksa sözleşme de, vefa da, uyumda yok olacaktır. Doğal hukuk olmadan ne erdem ve erdemsizliğin ne iyilik ve kötülüğün, ne de ödüllendirmenin ve cezalandırmanın imkânını olacağı gerçeğidir. Kanunun olmadığ 1 yerde hata ve suçtan bahsedilemez. Doğal hukuk olmasaydı her şey insan iradesinde temelini bulacak ve sorumluluk gereği davranış diye bir şeyden bahsedilemeyeceğinden insan, fayda ya da hazzın emrettiği veya kör ve kanunsuz içgüdünün rast gele sarıldığı eylemden başkasını yapamayacaktı (Toku, 2003:s.95-96). İnsanların ilişkilerinde daima altın kuraldan bahsetmeleri (kendine yapılmasını istemediğin şeyi başkasına yapma) ve yine küçük çocukların oyunlarında dürüstlük istemeleri bu tür doğal talepler, doğal hukukun apaçık delilleridir.

Genel olarak doğal hukuk savunucuları, "doğa" deyimini lisandaki mutat kullanışını aksine, "tabii bir akli kanuniyet" anlamında kullanırlar. Doğal hukuk anlayışına yönelik problem teşkil ede nokta, aklın bu çerçevedeki yeridir. "Akıl, beşeri ilişkilerin evrensel geçerliliği olan prensiplerini tayin etmeye mi muktedirdir, yoksa insan doğasında zaten var olan bu prensiplerin neler olduğunu keşfetmeye mi?" Bu sorunu cevabı dikkate alınarak doğal hukuk anlayışında iki temel görüş ortaya çıkmıştır. İlki, insan aklının bütün sosyal ve siyasal ilişkilere hâkim olabilecek evrensel geçerlikte etik ve hukuki prensipleri tayin etmeye muktedir olduğu varsayımına dayanan soyut rasyonalist teoridir. İkinci bakış açısına göreyse, bu prensipler toplumsal hayat sürecinde kendiliğinden, doğal olarak ortaya çıkarlar. Toplumsal ilişkilerin belirlenmesinde akı1, kısmi bir etkiye sahip olsa bile kurucu, kurgulayıcı boyutlarda bir etkiye sahip olduğu sanılmamalıdır. Bu açıdan bakıldığında Locke, kurucu rasyonalizm olarak adlandırılan doğal hukuk anlayışını benimsemez.

Doğal hukuku benimseyen düşünürler için doğal hukuk, insanların bir toplum ve devlet yönetimi altında yaşamaya başlamadan önce de var olan ebedi ve ezeli bir kuraldır. İnsanların, sahip olmak için insan olmaktan başka herhangi bir şartı gerektirmeyen; yaşama, özgürlük, mülkiyet ve güvenlik hakları gibi evrensel insan haklarının kaynağı ne din, ne insanların fayda ve zevkleri, ne toplumun ortak çıkarı, ne de devletin determinasyonudur. Bütün insanlar için geçerli olan evrensel insan haklarının yegâne kaynağı, aklın keşfettiği seküler doğal hukuktur.

17. yüzyılda ki doğal hukuk formülasyonu, devrimci bir nitelik taşıyordu. Daha önce de ifade ettiğimiz gibi doğal hukuk fikri, kimi zamanda klişeleşmiş eski hiyerarşileri yıkan, kimi zamanda bizzat devrimi meşrulaştırmışlar ya da devrimlerin kendilerini temellendirecekleri zemini sunmuşlardır.

Avrupa'da tarihsel süreç içerisinde önemli siyasal, askeri, yönetsel ve dinsel görevler toprak soyluların tekeline bırakılmıştı. Örneğin İngiltere'deki Lordlar Meclisi'nde üyelikler babadan oğula geçmekteydi. Toprak soylu (Aristokrat) olmayanların general olmaları olanaksızdı. Onuncu yüzyıldan başlayarak kentlerde gelişen ticaret ve sanayi, varlıklı, yeni bir toplumsal sınıfın doğmasına olanak vermişti. Zaman, bu kentsoylu (Burjuvazi) sınıfı ekonomik ve toplumsal açıdan daha da güçlendirirken, kapalı tarım ekonomisinin yıkılmaya yüz tutması toprak soyluların giderek zayıflamasına yol açıyordu. Fakat burjuvazi kesimin gelişmesine en büyük engel aristokratların doğuştan sahip bulundukları hukuksal ayrıcalıklardı. Bu hukuksal ayrıcalıklar ortadan kaldırılmadan burjuvazi kesimin gelişmesi ya da aristokratların karşısında tutunması asla mümkün olamazdı (Kışlalı, 2003:s.84-85). Bundan dolayı Rönesans'la birlikte; geleneksel aristokrasiye karşı varoluş mücadelesi veren burjuvazi özgürlük, eşitlik ve evrensellik iddiasındaki yeni siyasal rejim liberal demokratik sistemin inşasını gerçekleştirebilmek için evrensel insan hakları öğretisini kurgulamak zorunda kalmıştır. Yeni siyasal rejim liberal demokratik sistem meşruiyetini evrensel insan hakları kurmacasından alıyor iken, onun meşruiyet zeminini de rasyonalist doğal hukuk anlayışı oluşturmaktaydı.

Genel olarak doğal hukuk kuramına ya da kuramın öne çıkan örneklerine pek çok eleştiri getirilmiştir. Her ne kadar bu eleştirilerin tümüyle ele alınması ve değerlendirilmesi çok geniş bir çalışmanın konusu olabilirse de, Thomas Hobbes'un görüşlerine yer vermeden geçmek ona yapılmış bir haksızlık olacaktır. 
Thomas Hobbes (1588-1679) doğal hukukun varlığını kabul etmiş, ancak sivil topluma giren bireylerin haklarını doğal hukuka göre hareket etmek üzere sınırlayacaklarını belirtmiştir. Bu durumda toplumu bir karmaşa içerisine itecektir. Oysaki sivil topluma girmenin amacı karışıklık ve savaşı ortadan kaldırmaktır (Brian H. Bix, 2004: s.309).

Bu bağlamda Locke'un özgürlük ve eşitlik anlayışı Hobbes'tan farklıdır. Hobbes eşitliği insanların çeşitli güçlerinin toplamının birbirine aşağı yukarı denk olduğuna dayanır. Locke ise değersel bir eşitlikten söz eder. Yani Hobbes'un eşitliği bir güç eşitliği iken (Hobbes,2007:s.97), Locke'un eşitliği ahlaki bir eşitliktir. Hobbes'un özgürlüğünde ahlaken hiçbir sınır bulunmaz ve insanlar her şeye tam yetkilidir. Oysa Locke' da insanlar medeni bir özgürlüğe sahiptir. Bu özgürlük kişilerin her şeyi sınırsız yapabilecekleri anlamına gelmemektedir. Yani birinin özgürlüğü diğerinin özgürlük sınırlarının başladığ 1 yerde biter. Locke' un doğal durumdaki insanların işbirliğine yatkın ve irade özgürlüğünün sınırlarını bilen kişiler olarak tanımlaması ahlaki niteliktendir. Bunu sebebi de Tanrı'nın koyduğu doğal yasalar çerçevesinde insanların kendi kendilerini sınırlamalarına bağlıdır.

Usluya göre "Locke yasa ile hakkı; özgürlük ile ödevi birbirinin karşıtı olarak görmemektedir. Özgürlüğü ortaya çıkaran ve güvenle kullanılmasını sağlayan doğa ve aklın yasalarıdır. Özgürlük herkesin dilediğini yapabilmesi anlamına gelmez. Böyle bir durumda kimsenin özgürlüğünden söz edilemez. Locke’a göre Tanrı insanları onlara hiçbir ölçü koymadan yaratmış olamaz. Tanrı doğal hukuk ile insanlara davranışları için iyi ve kötünün ölçüsünü koyar. Yine Lock'a göre doğa durumunda herkesi bağlayan ve durumu yöneten bir doğa yasası vardır ve bu da akıldan gelir: herkes eşit ve bağımsız olduğundan hiç kimse diğerinin yaşamına, sağlığına, özgürlüğüne ya da malvarlığına zarar vermemelidir. Locke'un teorisini tek bir doğal hakla özetleyecek olursak, bu da her insanın kendisi üzerinde sahip olduğu mülkiyet hakkı olmalıdır. Locke kişinin kendisi üzerindeki mülkiyet hakkını 3 grupta toplamaktadır: hayat, özgürlük ve servet hakkı. Locke bir insan üzerinde başka bir insanın egemenliğinin bulunmayışını eşitliğe ve her insanın sadece Tanrı"nın mülkü olduğuna bağlamaktadır"(Uslu,2011:s.38-48)

\section{Sonuç}

Öyleyse şunu söyleyebiliriz: Ebedi ve değişmeyen bir doğal hukukun var olduğu ve hukuksal kararların amacının adaleti sağlamak olduğu düşüncesi insanlık tarihinde sürekli olarak var olduğu düşünülen bir gerçekliktir. Bir haklılaştırma zemini olarak insanlık tarihi boyunca doğal hukuk kuramının hiç değişmeyen niteliği, bütün yasaların geçerliliğini, onların nihai bir ölçüye, var olan bütün yasalardan daha da büyük bir kesinlikle bilinebilir ve değeri takdir edilebilir olan bir ideal hukuka atıfla sınama olanağının bulunduğu görüşünde saklıdır (Can, 2005:s.303-304). Bir haklılaştırma zemini olarak insanın varoluş serüveni içerisinde her zaman bulunmuş olan doğal hukuk, tarihte ilk kez sofistler tarafından insanlar arasındaki eşitlik esasını savunmak, köleliğe karşı çıkmak için kullanılmıştır. Daha önce bir "doğa" kavramının bile var olmadığı bunun Yunanlılarla ortaya çıktığını Strauss tarafından dile getirmişti ve doğal hukuk anlayışı kozmosu parçalayarak, insanlar arasındaki eşitlik esasını savunmak, köleliğe karşı çıkmak amacıyla sofistler tarafından başvurulmuş bir meşrulaştırma zeminine işaret etmekteydi. Doğal hukuk bir özgürlük bayrağı olması hasebiyle, Hıristiyanlarca büyük ölçüde benimsenmişti. Ancak kilise babaları din eksenli kendi dünya görüşlerini benimsetmek için meşrulaştırma zemini olarak din merkezli bir doğal hukuk fikrine başvurmuşlardır ve daha önceki insan doğasına ve rasyonalitesine dayanan doğal hukuk fikrine dini bir nitelik kazandırarak onu derin bir biçimde değiştirmişlerdir. Çünkü kilise dünya hegemonyası için uğraşıyordu ve bu hâkimiyeti sağlamak içinde köleliğe karşı özgürlüğü savunur görünmüş; despot yöneticiler karşısında, Tanrısal alana bağımlılığın gerçek özgürlük olduğunu öne sürmüştür. 17. Yüzyılda doğal hukuk sofizme dayalı seküler bir nitelik kazanmıştır. Geleneksel aristokrasinin siyasete egemen olduğu bir dünyada evrensel insan hakları söylemi, yükselmekte olan burjuvazinin güçlü bir silahıydı. Bu silahın meşrulaştırma kaynağı ise, elbette ki, hayat, hürriyet, mülkiyet, eşitlik ve güvenlik gibi argümanlara dayanan doğal hukuk fikriydi. Çünkü burjuvazi kesim, sermaye birikimi önündeki 
engelleri kaldırmak, aristokratların doğuştan getirmiş oldukları hakları ve ayrıcalıkları ortadan kaldırmak ve bu sayede onlarla eşit bir seviyeye ulaşmak, bununla beraber sosyal ve siyasal değişimi haklı göstermek istiyorlardı. Bütün bunları temellendirmek ya da haklılaştırma için doğal hukuk fikrine başvuruyorlardı. Geçmişte olduğu gibi günümüzde de doğal hukuk bir haklılaştırma kaynağı olarak başvurulan temel argümanlardan biri ya da en önemlisidir denebilir. Bugün dünyanın süper güçleri bu nosyonu edinmiş ve yapmış olduğu her türlü şiddet eylemini haklılaştırma için de doğal hukuk fikrinde temellenen evrensel insan hakları söylemine başvurmuş ve başvurmaktadır. Nasıl ki bugün bir meşrulaştırma zemini olarak doğal hukuk öğretisine başvuruluyorsa geçmişte olduğu gibi gelecekte de bu fikre başvurulacaktır. Doğal hukuk bir haklılaştırma zemini olarak insanlar için her zaman cezp ediciliğini koruyacaktır.

\section{KAYNAKÇA}

Ağaoğulları, M. A. ve Köker, L. (2004). Kral-Devlet ya da Ölümlü Tanrı, Ankara: İmge Yayınları.

Aral, V. (1991). Hukuk Felsefesinin Temel Sorunları, İstanbul: Filiz Kitabevi.

Arnhart, L. (2008). Plato'dan Rawls'a Siyasi Düşünce Tarihi,

(Çeviren: Ahmet Kemal Bayram). Ankara: Adres Yayınları.

Arslan, A. (2005). Felsefeye Giriş, Ankara: Adres Yayınları.

Bix, B. H. (2004). Doğal Hukuk: Modern Gelenek, (Cilt:6) Sayı: 2, (Çeviren: Ertuğrul

Uzun), İzmir: Dokuz Eylül Üniversitesi Hukuk Fakültesi Dergisi.

Can, N. (2005). Siyaset Felsefesi Problemleri, Ankara: Elis Yayınları.

Cevizci, A. (2007). On Yedinci Yüzyıl Felsefe Tarihi (2. Bask1). Bursa: Asa Kitabevi.

Cevizci, A. (2009). Felsefe Tarihi, İstanbul: Say Yayınları.

Ebensteın, W. (2005). Siyasi Felsefenin Büyük Düşünürleri, (Çeviren: İsmet Özel).

İstanbul:Şule Yayınları.

Gözler, Kemal,(2008), "Tabiî Hukuk ve Hukukî Pozitivizme Göre Adalet Kavramı", Y1l 4, Sayı 15, Kış, Muhafazakâr Düşünce.

Güriz, A. (2007). Hukuk Felsefesi, Ankara: Siyasal Kitabevi.

Hobbes,T, (2007), Leviathan, (Çev:Semih Lim), İstanbul ,Yapı Kredi Yayınları.

Kışlalı, A. T. (2003). Siyasal Sistemler: Siyasal Çatışma ve Uzlaşma, Ankara:

İmge Kitabevi.

Mengüşoğlu, T. (2008). Felsefeye Giriş (11. Baskı). İstanbul: Remzi Kitabevi.

Öktem, N. (1983). Hukuk Felsefesi, İstanbul: Üçdal Yayınları.

Özlem, D. (2001). Günümüzde Felsefe Disiplinleri (2. Bask1). İstanbul: İnkılâp Kitabevi.

Pieper, A. (2012). Etiğe Giriş (2. Baskı). (Çeviren: Veysel Atayman ve Gönül Sezer).

İstanbul: Ayrıntı Yayınları.

Strauss,Leo,(2011), Doğal Hak ve Tarih, (Çeviren: Murat Erşen), İstanbul: Say Yayınları.

Strauss, L. (1953). Natural Right and History, Chicago: The Universty of Chicago Press.

Toku, N. (2003). John Locke ve Siyaset Felsefesi, Ankara: Liberte Yayınları.

Toku, N. (2004). Felsefe Yazıları, İstanbul: Yeni Zamanlar Yayınları.

Torun, Y. (2005). Hugo Grotius'un Hukuk ve Siyaset Felsefesi, İstanbul:

Kaknüs Yayınları.

Türker, M,(2005), Etik Tarihindeki Temel Doğal Yasa Anlayışları ve Bu Anlayışlardaki

Dini Unsurlar, SayıXXII, İzmir:D.E.U.İlahiyat Fakültesi Dergisi.

Uslu, Cennet,(2011), Doğal Hukuk ve Doğal Haklar: İnsan Haklarının Felsefî Temelleri,

(2. Bask1), Ankara:Liberte Yayınları.

Wacks, Raymond,(2006), Phılosophy Of Law, Oxford University Press, New York.

Wild, John,(1953), Plato's Modern Enemies and The Theory of Natural Law,

University of Chicago Press. 